\title{
Study of influence of biological stimulating agents for germination of seeds of belladonna
}

\author{
O. Rudnyk-Ivashchenko, \\ doctor of agricultural sciences \\ O. Yaruta \\ Institute of Horticulture of NAAS
}

The purpose. Analysis and assessment of efficiency of application of biological stimulating agents of germination of seeds of belladonna dace (Atropa belladonna L.). Methods. Laboratory probes of seeds of 6years prescription of belladonna dace were carried out in 5 alternatives in 4-fold frequency (100 seeds in each alternative). Field tests were carried out in conditions of stationary experience with total area of sowing lot $20 \mathrm{~m} 2$, and registration one $-6 \mathrm{~m}^{2}$. Results. Influence of biological stimulating agents of germination of seeds of belladonna dace is specified. Advantage of gibberelin acid as stimulating agent in comparison with other alternatives is shown. As to quantitative parameters of a flower and fruits of belladonna at use of different stimulating agents for germination the most effective ones were solutions gibberelin and amber acids. Conclusions. The solution of gibberelin acid (A3) $1 \%$ has appeared in experiences the most efficient stimulating agent for germination of seeds of belladonna. Thus the applied stimulating agents for germination of seeds essentially did not influence growth and development of plants of belladonna, transition of phenophases by them, formation of the photosynthetic apparatus - leaf blades, amount of flowers and fruits.

Key words: drug plants, belladonna dace, stimulating agents of germination of seeds, bioraw material.

Analysis and evaluation of the effectiveness of biogenetic stimulants normal germination belladonna (Atropa belladonna L.). Methods. Laboratory studies seeds 6-year-old ordinary herb conducted in 5 versions in double repetition of 100 pieces. seeds in each variant. Variants of the experiment: 1) control; 2) aloe juice + ice water; 3) succinic acid $\mathrm{C} 4 \mathrm{H} 6 \mathrm{O} 4$; 4) hiberelin of acid A3; 5) sowing seeds in climatic conditions the camera clock temperature $33 \ldots 350 \mathrm{C}$ and $98 \%$ humidity. Field experiments were conducted in a residential area sown experiment total area - $20 \mathrm{~m} 2$, accounting - $6 \mathrm{~m} 2$, repetition - three. Sowing was carried out in Q4 of April at a depth of seeding $-1.5 \mathrm{~cm}$. Care of crops was to hand weeding of weeds in the rows for the extent of their appearance. Results. The influence of biogenetic stimulators of germination of normal herb that has shown superiority hiberelin of acid as a catalyst in comparison to other options, but no significant impact on the passage of plants interphase periods. The longest period vegetation was a variant using succinic acid as a stimulant - 192 days, the shortest - in the version with hiberelin of acid - 180 days. Regarding the development of plants is under control they formed the largest area of leaf blade $-135 \mathrm{~cm} 2$, which is more than $27 \mathrm{~cm} 2$ plants in the version with the use of succinct acid (an area with the least puff apparatus). For quantitative parameters herb flowers and fruits for the use of different germination stimulants were the most effective solutions hiberelin and succinct acid. Conclusions. Hiberelin of acid solution (A3) $1 \%$ in the experiments was the most effective stimulant for germination but most ordinary herb leaf plate area in field experiments formed on the control (without stimulants germination). 4 However, stimulants used for seed germination did not significantly affect the growth and development of plants belladonna, passage of phonological phases formation of the photosynthetic apparatus - leaf plate, the number of flowers and fruits that are most likely biological characteristics of the species, which will be the subject of further research. Key words: herbs, belladonna usual, seed germination stimulants, biological raw materials. Formulation of the problem. In modern conditions increase crop yields can be achieved on the basis of high culture of agriculture through scientifically proven environmentally sound use of fertilizers and pesticides, widespread introduction of advanced technologies with minimal use of chemicals. With regard to medicinal plants, the requirements for their cultivation is increased with minimal use of pesticides. Improving plant productivity belladonna usual due to the need for procurement of medicinal raw materials, requires the development of 
adaptive methods of cultivation, especially in cases where the zone is not traditional for its cultivation and medicinal plant to quality in certain climates. Germination of seed - an important step in growing plants, as this will depend on wild seed germination and ultimately - yield. This is important in agricultural practice. It is also important that the natural plant growth stimulants can replace chemical stimulants that are hazardous to health, especially when it comes to medicinal plants [1]. The aim of research was to establish the efficacy of biogenetic growth promoters in conventional belladonna (Atropa belladonna L.), thereby increasing vigor, seed germination and yield high-quality raw materials. The results of research actions stimulants for germination herb, aloe juice, succinct acid, hibberellin acid. The object of the research was to plant seeds usual herb (Atropa belladonna L.). This heat-loving perennial herb of the family Solanaceae. In Ukraine, the Union at the time it was grown in the Carpathian region and Crimea for the pharmaceutical industry with raw materials. The influence of belladonna ordinary human organism is determined by the prevailing influence of atropine and scopolamine, which have a wide range of pharmacological action [2, 3]. 5 Results of laboratory analysis for seed germination parties received under the "Genetic resources" proved not comforting. With 100 seeds sprouted only one. Presowing - stratification for 2 months at a temperature of $0 \ldots 5^{\circ} \mathrm{C}$ did not produce positive results. Materials and methods of research. Studies conducted in the laboratory of floral and ornamental and medicinal plants Horticulture Institute of NAAS of Ukraine. Seeds germinated in accordance with generally accepted methodology (2002) [4]. For seed germination used a 6-year-old ordinary herb that is being stored at room temperature in a dry place. Experiment laid in 5 versions in double repetition of 100 pieces. seeds in each variant. Variants of the experiment: 1) control; 2) aloe juice+melt water; 3) succinct acid $\mathrm{C} 4 \mathrm{H} 6 \mathrm{O} 4$; 4) hiberelin acid A3; 5) sowing seeds in climatic conditions the camera clock temperature $33 \ldots 35^{\circ} \mathrm{C}$ and $98 \%$ humidity. To study the growth and development of plants for the stages of organogenesis experiments laid in the experimental field NAAS Institute of Horticulture in 20142015 years. The selection and evaluation of individual plants was carried out by biomorphological, agronomic characteristics. The relief pilot areas equal. Ground dark gray ashed, on carbonate loess, typical of the northern steppes of Ukraine. Soil analysis performed in the laboratory of Agricultural Chemistry Institute of Horticulture NAAS of Ukraine. The content of humus in the topsoil $(0-40 \mathrm{~cm})$ is $2.3 \%$, easy hidrolizuyuchi nitrogen (by Tyurin and Kononov) from 78.4 to $98.0 \mathrm{mg} / \mathrm{kg}$, mobile forms of phosphorus - 93,2-180,9 mg / $\mathrm{kg}$, exchangeable potassium (for Kersanovym) - 106,1-202,8 $\mathrm{mg} / \mathrm{kg}$. The reaction of soil solution is acidic $(\mathrm{pH} 5.3$, respectively-5.8 and 5.5-6.1). The total area sown area was $20 \mathrm{~m} 2$, accounting - $6 \mathrm{~m} 2$, repetition six times. Soil preparation, sowing and care for plants was performed according to the recommendations herb growing in Crimea. Sowing is carried out in Q4 of April at a depth of seeding $-1.5 \mathrm{~cm}$. Weather conditions during the studies differed significantly by temperature conditions, precipitation and humidity that had significant deviation from the average of long-term rules that provided an 6 opportunity to more fully explore the biological and morphological features of plants belladonna, their adaptability to growing conditions and the ability to implement biological potential. The selection and evaluation of individual plants was carried out by geomorphological, agronomic characteristics. Dynamics of increase of leaf surface was determined by the method of Nichiporovich A.A. [5] $\mathrm{Sn}=0,65 \times a \times b$, where: $\mathrm{Sn}$ - area of a sheet $\mathrm{cm} 2$; and the widest part of the leaf, $\mathrm{cm} ; \mathrm{b}$ - the length of the leaf, $\mathrm{cm} ; 0.65$ - coefficient reflecting configuration sheet. Results and discussion. Aloe juice is one of the most famous and accessible biogenic stimulant herbal with a complex chemical composition. He is represented by tar, amino acids (over 20) phenols, essential oils complex, volatile, trace elements [6]. Succinct acid - a growth regulator that affects seed germination and helps plants better absorb substances from the soil, and is adaptogen (helps plants tolerate stress easier and faster to recover from transplant or develop normally under unfavorable conditions) [7]. Hibberellin acid a class of substances like organic acids. Related to Plant hormones (phytohormones). It stimulates the growth and development of plants, promotes seed germination. The chemical nature - diterpenovi polycyclic acids that belong to carboxylic acids. The basic structure of hibberellin find HK9 [8]. The solution was prepared by the method of P.P. Korosteleva (1964) [9]. Aloe juice was made from the leaves of the lower tier of the stem 5-year plant with its subsequent storage of up to 7 days at a temperature of $+20^{\circ} \mathrm{C}$, thereby creating extreme conditions (temperature decrease, the absence of light) to isolate tissue layers. After the period of exposure, obtained by direct extraction of aloe juice for which in contrast to the freshly squeezed juice was characterized by rare, not gelatinous texture, brown color. Herb seeds placed in a solution of 
ordinary aloe juice + melt water in a ratio of $1: 1$ for 24 hours. In these embodiments, for soaking seeds and herb conventional succinct acid hibberellin acid used, as in the previous experiment, $1 \%$ of the solution. 7 Germinated seeds in Petri dishes at temperatures 22...25o C. The duration of the experiment - 23 days. Counts made by state sort testing methods $(2000,2001)$. Sprouted seed culture in the first 7 days counted every day, and then - at 10 and 13 days. Not sprouted seed culture was transferred to a new Petri dish and continued to account for a further ten days. As a result, data were obtained that showed superiority hibberellin acid as a stimulant herb seed germination, compared with other options (picture). The energy of germination of seeds belladonna 3137462458677129 A solution of aloe juice + melt water 1:1 Succinic acid 1\% Hibberellin acid (A3) 1\% Without a growth stimulator in terms of the climate chamber Options Germination of seeds \% The energy of germination of seeds, \% At bookmarks of experience in the field for control has been an option, which the plants grown in the climatic conditions of the camera (without a stimulator of growth for plants). Planting plants in soil in all versions developed well. However, it should be noted if the phase of "appearance leaves 4" plants on the version of the application. to the hibberellin occurred 2-3 days later than the other options, the next phase of "start branching" 3-5 days earlier and lasted the longest compared with other options (Table. 1). Belladonna plants bloom in all versions almost simultaneously. It should be noted that all phases of growth and development of plants herb only during the "early ripening" had significant fluctuations for the duration of variants. Table 1 Characteristics of plants Belladonna for the duration of interphase the growing season, the average for the 2013-2015 biennium. Phases of growth and Options 8 The longest period vegetation was a variant using succinic acid as a stimulant, and was 192 days. Regarding the formation of the photosynthetic apparatus - leaf plants plate to significant advantages for the experiment variants were observed, unless you consider the plant under control. That control of belladonna plants formed the largest area of leaf blade $-87,5 \mathrm{~cm} 2$, which is more than $17.7 \mathrm{~cm} 2$ plants in the version with the use of succinic acid layer device which formed the smallest area (Table. 2). The research results are reliable, as the coefficient of variation in all variants was within allowable. This can be explained by the fact that solutions applied proved good stimulant for germination, but they had no effect on plant development in ontogenesis. Table 2 Characteristics of the plant on the grounds of belladonna leaf the average for the 2013-2015 biennium. Options Length leaf, $\mathrm{cm}$. Sheet width, $\mathrm{cm}$. Area leaf plate, cm. 2 M+mM V,\% M+mM V,\% M+mM V,\% Control 17,9+0,31 3,9 6,9+0,61 4,2 80,3+0,42 3,7 development Control aloe juice+ melt water Succinic acid $\mathrm{C} 4 \mathrm{H} 6 \mathrm{O} 4$ Hibberellin acid A3 duration, days stairs plants 303031274 leaf appearance in plants 26262528 start branching 23252320 branching 7557 budding phase 88910 beginning of flowering 5433 full bloom 8776 formation of the fetus 14141212 beginning of ripening 117178 full ripening 35374039 Total 1851831901789 Aloe juice+ meltwater 17,7+0,36 4,4 6,5+0,19 3,8 74,8+0,28 3,5 Succinic acid (C4H6O4) 16,2+0,21 3,9 6,3+0,23 4,0 66,3+0,27 4,1 Hibberellin acid (A3) 16,0+0,47 3,6 6,7+0,21 4,5 69,7+0,34 4,2 As used in pharmacology seeds not only belladonna but to a greater extent biological materials, it is very important to plant deadly nightshade formed a large vegetative mass. In average years of research formed the largest number of flowers the plant belladonna in the version of the application solution hibberellin acid $-7.5 \mathrm{pc}$. the average for the experiment, the lowest $(6.1$ pc.) -to control (Table. 3). In an embodiment of succinic acid belladonna flower best developed compared with other options: they whisk her longest diameter had the highest settings - 2.01 and $1.54 \mathrm{~cm}$ respectively. Table 3 Characteristics measurable signs of belladonna flower and fruit by using different promoters germination, the average for 2013-2015 Flower Fruit number, pieces corolla, cm length diameter the number diameter $\mathrm{cm} \mathrm{M+mM} \mathrm{V, \%} \mathrm{M+mM} \mathrm{V, \%} \mathrm{M+mM} \mathrm{V, \%} \mathrm{M+mM} \mathrm{V, \%} \mathrm{M+mM} \mathrm{V, \%} 123456$ 78910 Control 70+1,66 6,8 1,7+0,09 0,26 1,4+0,06 0,20 95+2,15 8,3 1,3+0,05 0,19 65+1,60 5,3 1,6+0,08 $\begin{array}{lllllllllllllllll}0,25 & 1,7+0,09 & 0,26 & 106+3,2 & 8,9 & 1,0+0,01 & 0,10 & 47+0,83 & 3,5 & 1,4+0,06 & 0,20 & 1,8+0,09 & 0,29 & 110+3,5 & 9,0\end{array}$ $1,0+0,010,1069+1,106,71,1+0,02 \quad 0,081,4+0,06 \quad 0,2090+2,137,8 \quad 1,8+0,090,2985+1,967,31,9+0,10$ $\begin{array}{llllllllllllllllll}0,31 & 1,0+0,01 & 0,10 & 94+2,15 & 8,5 & 2,0+0,11 & 0,33 & 83+1,82 & 7,0 & 1,1+0,02 & 0,08 & 0,9+0,01 & 0,08 & 80+1,98 & 6,9\end{array}$ $1,3+0,050,1960+1,564,91,4+0,050,201,2+0,03 \quad 0,1175+1,65 \quad 7,31,8+0,070,2980+1,98$ 6,9 $1,3+0,04$ $\begin{array}{llllllllllllllll}0,19 & 1,3+0,04 & 0,19 & 84+1,83 & 7,6 & 1,6+0,06 & 0,25 & 70+1,66 & 6,8 & 1,1+0,02 & 0,08 & 0,8+0,01 & 0,07 & 88+2,10 & 7,9\end{array}$ $2,0+0,100,3378+1,716,71,6+0,060,251,5+0,070,2192+2,138,02,1+0,120,32 X^{*} 71+1,66,11,4+0,05$ $0,191,3+0,060,1794+3,18,11,5+0,060.24$ Aloe juice+ meltwater $63+1,525,21,9+0,100,310,9+0,01$ $\begin{array}{lllllllllllllll}0,08 & 80+1,98 & 6,9 & 1,3+0,05 & 0,19 & 70+1,66 & 6,8 & 1,6+0,08 & 0,25 & 1,0+0,01 & 0,10 & 85+1,96 & 7,3 & 1,0+0,01 & 0,10\end{array}$ 
$72+1,837,11,7+0,090,261,0+0,010,1060+1,564,90,8+0,010,0768+1,086,51,9+0,100,311,1+0,02$ $\begin{array}{llllllllllllllllll}0,11 & 63+1,52 & 5,1 & 1,0+0,01 & 0,10 & 80+1,98 & 6,9 & 1,5+0,06 & 0,21 & 0,8+0,01 & 0,07 & 59+1,37 & 4,7 & 1,5+0,06 & 0,21\end{array}$ $74+1,547,2$ 2,0+0,11 0,33 0,8+0,01 0,07 65+1,60 5,3 1,8+0,09 0,29 69+1,10 7,0 1,4+0,05 0,20 1,5+0,04 $\begin{array}{lllllllllllllllllll}0,21 & 71+1,65 & 6,8 & 2,0+0,10 & 0,33 & 72+1,73 & 7,1 & 1,6+0,08 & 0,25 & 1,2+0,03 & 0,11 & 83+1,82 & 7,0 & 1,2+0,04 & 0,11\end{array}$ $88+2,097,91,9+0,100,311,6+0,050,2575+1,657,3 \quad 1,6+0,08 \quad 0,2580+1,98 \quad 6,92,0+0,110,331,4+0,04$ $0,2079+1,866,81,2+0,030,1110 \times 74+1,66,81,7+0,080,27 \quad 1,1+0,060,1472+2,436,21,3+0,060,18$ Succinic acid 68+1,08 6,9 1,9+0,10 0,31 1,1+0,02 0,11 86+1,96 7,4 1,6+0,07 0,25 75+1,65 7,3 1,8+0,09 $\begin{array}{llllllllllllllll}0,29 & 1,4+0,05 & 0,20 & 91+2,18 & 7,8 & 1,4+0,05 & 0,20 & 77+1,69 & 6,6 & 2,0+0,11 & 0,33 & 2,0+0,11 & 0,33 & 82+1,82 & 7,5\end{array}$ $1,6+0,080,2570+1,666,82,2+0,130,351,0+0,010,1094+2,138,2 \quad 2,0+0,110,3383+1,827,51,9+0,10$ $\begin{array}{llllllllllllllll}0,31 & 0,8+0,01 & 0,07 & 105+3,2 & 8,9 & 1,8+0,09 & 0,29 & 65+1,60 & 5,3 & 1,7+0,08 & 0,26 & 1,4+0,05 & 0,20 & 86+1,96 & 7,4\end{array}$ $1,0+0,010,1073+1,767,02,0+0,110,331,7+0,090,2690+2,137,8$ 1,5+0,06 0,21 78+1,71 6,7 2,4+0,15 $\begin{array}{lllllllllllllllll}0,38 & 1,8+0,09 & 0,29 & 80+1,98 & 6,9 & 1,2+0,04 & 0,11 & 83+1,82 & 7,0 & 2,2+0,13 & 0,35 & 2,0+0,11 & 0,33 & 60+1,56 & 4,9\end{array}$ $1,4+0,050,2089+2,107,62,0+0,110,332,2+0,130,3578+1,706,71,8+0,090,29 \times 77+1,76,72,01+0,10$ $0,321,5+0,080,2286+2,37,3 \quad 1,5+0,07 \quad 0,23$ Hibberellin acid $90+2,137,81,0+0,010,101,0+0,010,10$ $96+2,158,51,3+0,050,1973+1,767,01,3+0,040,190,9+0,010,0882+1,827,41,5+0,060,2186+2,037,4$ $1,7+0,090,261,2+0,040,1186+1,967,61,7+0,080,2679+1,816,92,0+0,110,331,3+0,030,1985+1,84$ $7,52,0+0,110,3383+1,827,52,3+0,140,38$ 1,1+0,02 0,1192+2,08 8,0 2,1+0,12 0,34 90+2,13 7,8 1,8+0,09 $\begin{array}{lllllllllllllll}0,29 & 1,5+0,06 & 0,21 & 80+1,98 & 6,9 & 1,9+0,10 & 0,31 & 95+2,15 & 8,3 & 1,5+0,06 & 0,21 & 1,6+0,07 & 0,23 & 89+2,09 & 7,8\end{array}$ $1,6+0,070,2584+1,957,42,0+0,110,331,2+0,040,1198+2,198,4 \quad 1,8+0,090,2989+2,107,82,4+0,15$

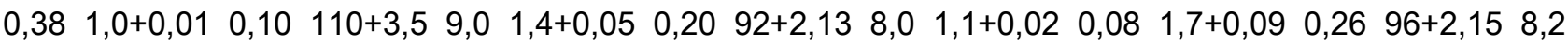
$1,6+0,070,25 \times 87+1,97,51,7+0,080,251,2+0,060,1592+1,97,91,6+0,080,26 X^{*}$-average value As for fruit, then the number on the plant were the largest in the version without the use of stimulants germination (under control) - 94 pcs. on the plant, the least in the version aloe juice + melt water -72 pcs., while their best fruit size formed in the version with hibberellin acid $-1.6 \mathrm{~cm}$. (see. Table. 3). Studies on the biological characteristics of belladonna plants and the development of elements of technology of cultivation in foreststeppe zone will continue.

\section{Conclusions}

1. Hibberellin acid solution (A3) $1 \%$ in the experiments was the most effective stimulant for germination belladonna usual. 2. In experiments using various stimulants seed germination were obtained unexpected results. The largest area of leaf lamina formed on the control (without stimulants germination). 3. The results showed that the use stimulants for germination did not significantly 11 affect the growth and development of plants belladonna, following phonological phases, the formation of the photosynthetic apparatus - leaf plate, the number of flowers and fruits rather have biological characteristics of species that will be subject to the following research.

\section{Bibliography}

1. Pushkyna H.P. Prymenenye rehulyatorov rosta pry vыrashchyvanyy belladonnы/H.P. Pushkyna, H.L. Sydel'nykov//Materyalы mezhdunar. nauch. konf. 75 let VYLAR «Henetycheskye resursы lekarstvennыkh rastenyy». - M., 2006. - S. $380-384$.

2. Suchorska K. Laser radiation as faktor stimulating Datura innoxia Mill, mid Atropa belladonna L. seed germination/K. Suchorska//Ann. Warsaw Agr. Univ. SGGW-AR: Hortic. — Warsaw, 1989. - T. 15. — R. 9 12.

2. Belladonna obsknovennaya. Atropa belladonna L./R.V. Kutsyk, B.M. Zuzuk, A.T. Nedostup, T. Petsko//Provyzor. - L., 2003. - S. 11 - 23.

4. Herbal Belladonna Tollkirschenkraut//Zbl Pharmakother und laboratories diagen. $-1990 .-129$, \# 1. -P. $53-55$.

5. Nasinnya sil's'kohospodars'kykh kul'tur. Metody vyznachannya yakosti. DSTU $4138-2002$. - K.: Derzhspozhyvstandart Ukrayiny, 2003. - 173 s. - (Natsional'nyy standart Ukrayiny).

6. Singh G. Control of leaf spot diseace of belladonna caused by Ascochyta atropae/R.V. Singh, I.S. Bisht//Indian Phytopathol. - 1985. - V. 38, \# 1. - R. 183 - 184. 
7. Nychyporovych A.A. Fotosyntez y voprosu produktyvnosty rastenyy/N.A. Nychyporovych. - M.: AN SSSR, 1963. - $64 \mathrm{~s}$.

8. Rabynovych A.M. Lekarstvennыe rastenyya Rossyy/A.M. Rabynovych, S.A. Rabynovych. - M.: Arnebyya, 2005. - S. $63-66$.

9. Vlyyanye proyzvodnыkh yantarnoy kyslotы na produktyvnost' ozymoy pshenytsы/L.A. Kononenko, V.Y. Mel'nykov, P.V. Skotnykov, L.P. Skotnykova//Zernovoe khozyaystvo Rossyy. — 2010. — \# 3 (9). — S. 9 12.

10. Lysytsya A.V. Stymulyuvannya prorostannya nasinnya polimernymy pokhidnymy huanidynu/A.V. Lysytsya//Nauk. dopovidi NUBiP. - 2010 (19). - S. 13 - 17.

11. Carvalho M.L. Study of trace element concentration by EDXRF spectrometry/M.L. Carvalho, J. Brito, M.A. Barreois//X-Ray Spectrometry. - 1998. - V. 27. - P. $198-204$.

12. Korostelev P.P. Pryhotovlenye rastvorov dlya khymyko-analytycheskykh rabot/P.P. Korostelev. - M.: Nauka, 1964. - $399 \mathrm{~s}$. 